\title{
Developmental anatomy of Cyperus laxus (non-Nranz) and Fimbristylis dichotoma (Kranz) (Cyperaceae, Poales) and tissue continuity
}

\author{
SHIRLEY MARTINS ${ }^{1}$ and VERA L. SCATENA ${ }^{2}$ \\ ${ }^{1}$ Centro de Ciências Biológicas e da Saúde, Universidade Estadual do Oeste do Paraná (Unioeste), \\ Caixa Postal 000711, 85819-110 Cascavel, PR, Brasil \\ ${ }^{2}$ Departamento de Botânica, Instituto de Biociências, \\ Universidade Estadual Paulista, Caixa Postal 199, 13506-900 Rio Claro, SP, Brasil
}

Manuscript received on October 11, 2011; accepted for publication on April 12, 2012

\begin{abstract}
The Cyperaceae species are present in different ecosystems and constitute the herbaceous extract. Of the approximately 5,500 species of the family; a third has Kranz anatomy, representing an important characteristic of the taxonomy and phylogeny of the group. In Cyperus laxus L. (non-Kranz) and Fimbristylis dichotoma Vahl (Kranz), development begins with germination that is marked by the emergence of the coleoptiles, followed by the primary root, which is ephemeral. The rhizome originates from the mesocotyl and it promotes the vascular connection between the roots, leaves and scapes. The continuity of the tissues is evidenced by the presence of an endodermis and pericycle in all vegetative organs. Leaves and scapes differ between the two species by the arrangement of mesophyll cells, which is regular in Cyperus laxus (non-Kranz) and arranged radially in Fimbristylis dichotoma (Kranz). Also differ in the number of bundles sheaths: two in Cyperus laxus (non-Kranz) and three in Fimbristylis dichotoma (Kranz). The outer bundle sheath in both species constitutes the endodermis, and the inner sheath in Cyperus laxus and the middle and inner sheaths in Fimbristylis dichotoma constitute the pericycle.
\end{abstract}

Key words: pericycle, endodermis, Casparian strips, seedling.

\section{INTRODUCTION}

Cyperaceae is one of the 10 largest Angiosperm families and it is the second family of the Poales order (Govaerts et al. 2007). This family is cosmopolitan (i.e., occurring in diverse ecosystems) and located mainly in open areas (Goetghebeur 1998) and disturbed environments (Bryson and Carter 2008). The family consists of approximately 5,500 species (Govaerts et al. 2007), and ca. 1,500 of these have Kranz anatomy (Bruhl and Wilson 2007), which is represented by a set of structural modifications that are related to $C_{4}$ photosynthesis (Sage 2004).

Correspondence to: Shirley Martins

E-mail: shirley_botany@yahoo.com.br
Cyperus laxus L. (non-Kranz) and Fimbristylis dichotoma Vahl (Kranz) are present in tropical and subtropical regions, mainly at the edges of forests and in open areas of different ecosystems (Alves et al. 2009). They are also considerate weed plants that are common in disturbed areas (Bryson and Carter 2008).

The anatomical studies of Cyperaceae usually have emphasized taxonomy (Govindarajalu 1974, Metcalfe 1971, Naczi 2009, Hefler and LonghiWagner 2010), and studies on anatomical development have been restricted to a few species that are of economic importance, such as Cyperus rotundus (Wills and Briscoe 1970), Cyperus esculentus (Wills 
et al. 1980, Gifford and Bayer 1995) and Cyperus papyrus (Menezes et al. 2005). In general, studies on anatomical development are restricted to a description of only one organ, such as the roots in Cyperus giganteus (Rodrigues and Estelita 2004); rhizomes in Cyperus esculentus (Bendixen 1973), Cyperus giganteus (Rodrigues and Estelita 2002) and Scleria (Lima and Menezes 2009); and leaves in Cyperus eragrostis (Soros and Dengler 1996) and Cyperus giganteus (Rodrigues and Estelita 2003).

In studies of development, only Menezes et al. (2005) and Lima and Menezes (2009) refer to the continuity of the tissues, which is marked by the presence of the endodermis and pericycle in all vegetative organs (Menezes et al. 2005). The endodermis and pericycle are structures that are often related to roots (Esau 1965); however, there are a few reports of these structures being present in other organs, such as the stem and leaf (Lersten 1997, Menezes et al. 2005).

For Cyperaceae, studies on anatomical development in the Kranz and non-Kranz species are important to determine the origin and distribution of the tissues in the plant as a whole. Thus, the developmental anatomy of Cyperus laxus (non-Kranz) and Fimbristylis dichotoma (Kranz) was studied to describe the origins of and verify the tissue continuity in different vegetative organs.

\section{MATERIALS AND METHODS}

Cyperus laxus L. (S. Martins 413, 417; P.A. Braga 14) and Fimbristylis dichotoma Vahl (S. Martins 414, 420; V.L. Scatena 343, 341) were collected in their natural habitat, disturbed areas in southeastern Brazil. Fimbristylis dichotoma is dominant in open areas, and Cyperus laxus is dominant in shaded areas. Voucher materials were deposited at the Herbarium of the Department of Botany, Universidade Estadual Paulista (HRCB).

For the anatomical study, individuals at different stages of development were collected, fixed in FAA 50 (Johansen 1940) and stored in 70\% ethanol. Mature achenes were allowed to germinate on filter paper that had been humidified with distilled water at $\left[30^{\circ} \mathrm{C}\right]$ in a B.O.D incubator. Monitoring was performed daily to observe the germination and the post-seminal stages of development.

Embryos and portions of young and mature vegetative organs (root, rhizome, leaf and scape) were dehydrated in an ethyl series and then they were embedded in historesin (Leica Historesin Embedding Kit, Nussloch, Germany) (Feder and O'Brien 1968). Paradermic sections of embryos and longitudinal and transverse sections of young and mature vegetative organs were performed on a rotary microtome. The sections were stained with periodic acid-Shiff's reagent (PAS reaction) and toluidine blue (Feder and O'Brien 1968) and mounted in Entellan (Merck, Darmstadt, Germany). Transverse sections of the medial region of all mature vegetative organs were also made, stained with basic fuchsin and Astra blue (Roeser 1972) and mounted in glycerin jelly.

Images were obtained using a Leica DFC 290 digital camera (Leica Microsystems Ltd., Heerbrugg, Germany) coupled to a Leica DMLB microscope (Leica Microsystems, Wetzlar, Germany), and the Leica IM50 image manager v. 5.0 software was used for analysis (Leica Microsystems, Wetzlar, Germany).

\section{RESULTS}

Cyperus laxus (non-Kranz) (Fig. 1A) and Fimbristylis dichotoma (Kranz) (Fig. 1B) are herbaceous, perennial and have rhizomes. The fruit is an achene (Fig. 1C), and the seed contains a differentiated embryo with coleoptiles (co) facing the micropyle and the radicle (ra) in a lateral position (Fig. 1D). Germination occurs within one to three days after the achene is imbibitioned, and the first structure to emerge is the coleoptiles, followed by emergence of the primary root (pr) (Fig. 1E-G). The coleoptile is green and tubular, involving the eophylls (eo) (Fig. 1G, H). In seedling 
development, the primary root degenerates, and the adventitious roots (ar) originate from the pericycle in the mesocotyl (Fig. 1I). In the seedling stage, vascular connection among the mesocotyl, roots and leaves occurs (Fig. 1I). The mesocotyl then develops into the rhizome (Fig. 1J), and in the young stage present Casparian strips in the endodermal cell walls (arrows in Fig. 1K).

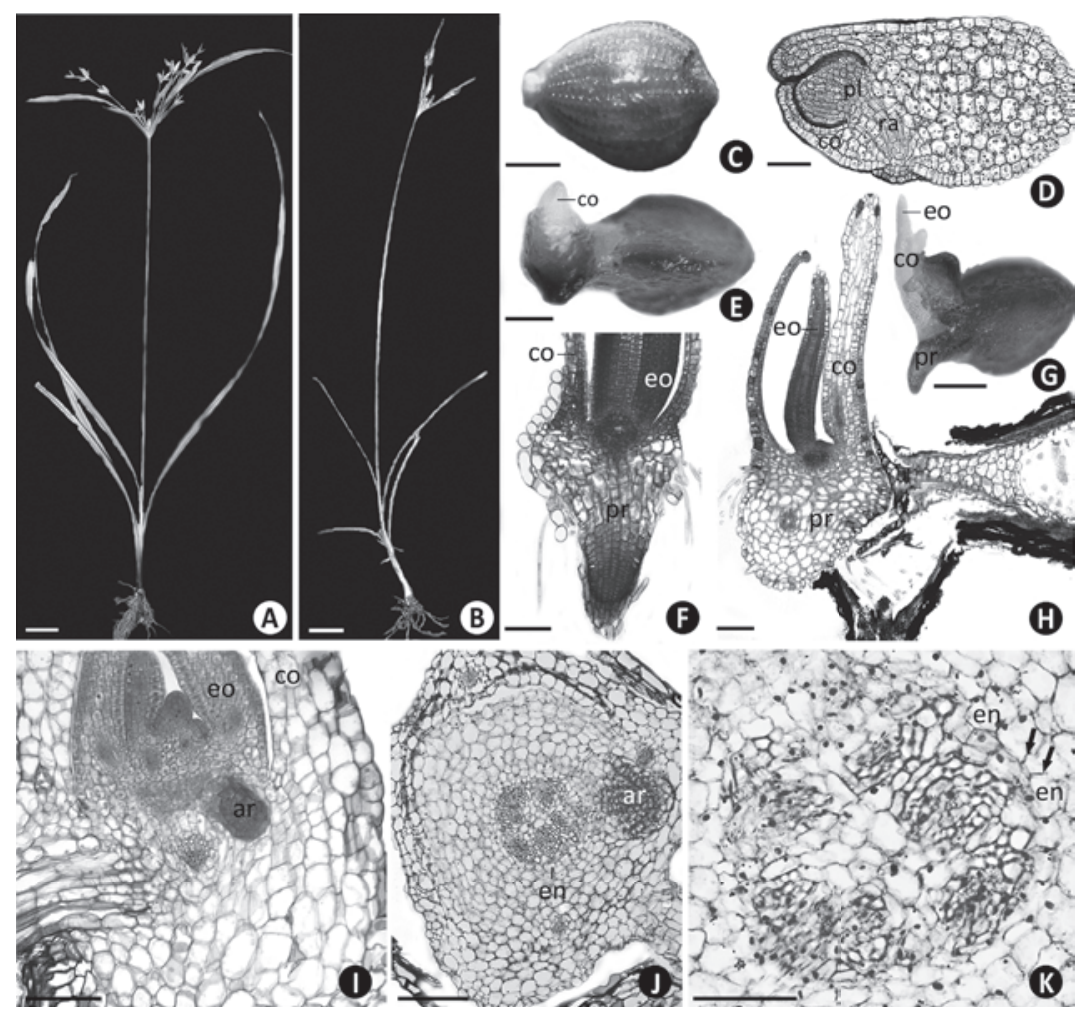

Fig. 1 - Morphological and anatomical aspects of Cyperaceae species: Cyperus laxus L. and Fimbristylis dichotoma Vahl. A. Cyperus laxus, habit; B-C. Fimbristylis dichotoma; B. Habit; C. Achene; D. Cyperus laxus, general view of the embryo in paradermic section; E-H. Morphology and anatomy of the post-seminal stages of development in Cyperus laxus (E, G, H) and Fimbristylis dichotoma (F); I-K. Cyperus laxus; I. General view of the mesocotyl; J. General view of young rhizome showing the radial cells originating from the precursor cells of the endodermis; K. Detail of the young rhizome showing Casparian strips in the endodermal cells (arrows). ar = adventitious root; $\mathrm{co}=$ coleptile; en $=$ endodermis; $\mathrm{eo}=$ eophyll; $\mathrm{pr}=$ primary root; $\mathrm{ra}=$ radicle. Bars $=2 \mathrm{~cm}(\mathbf{A}, \mathbf{B}) ; 1 \mathrm{~cm}(\mathbf{C}, \mathbf{E}, \mathbf{G}) ; 100 \mu \mathrm{m}(\mathbf{F}, \mathbf{H}, \mathbf{I}, \mathbf{J}) ; 50 \mu \mathrm{m}(\mathbf{D}, \mathbf{K})$.

A mature rhizome possesses a vascular plexus that originates from the pericycle and promotes vascular connection with the roots (Fig. 2A). In this same region, the connection between the rhizome and the leaves and scapes occurs through the procambial strands and ground meristem tissues (Fig. 2A-C). The endodermis (en) and pericycle (pe) of the adventitious root is continuous with that of the rhizome (Fig. 2D-E). Detail of the tissue connections between the rhizome and the root is showed in Fig. 2E. In the young root, the precursor cells of the endodermis divide periclinally and give rise to derivative cells of the endodermis that form radial rows on the internal cortex and part of the medial cortex (Fig. 2F). In the young root, Casparian strips are present in the endodermal 
cells (arrows in Fig. 2G). In the mature root, the endodermis has thick-walled cells (Fig. 2H), and the pericycle has slightly thick-walled cells (Fig. 2H). During root differentiation, occurs the formation of aerenchyma schizo-lisygenous in the median cortex; first by the separation of the cell walls (arrowheads in Fig. 2F) and after by cell lyses of the cell walls (arrows in Fig. 2H).
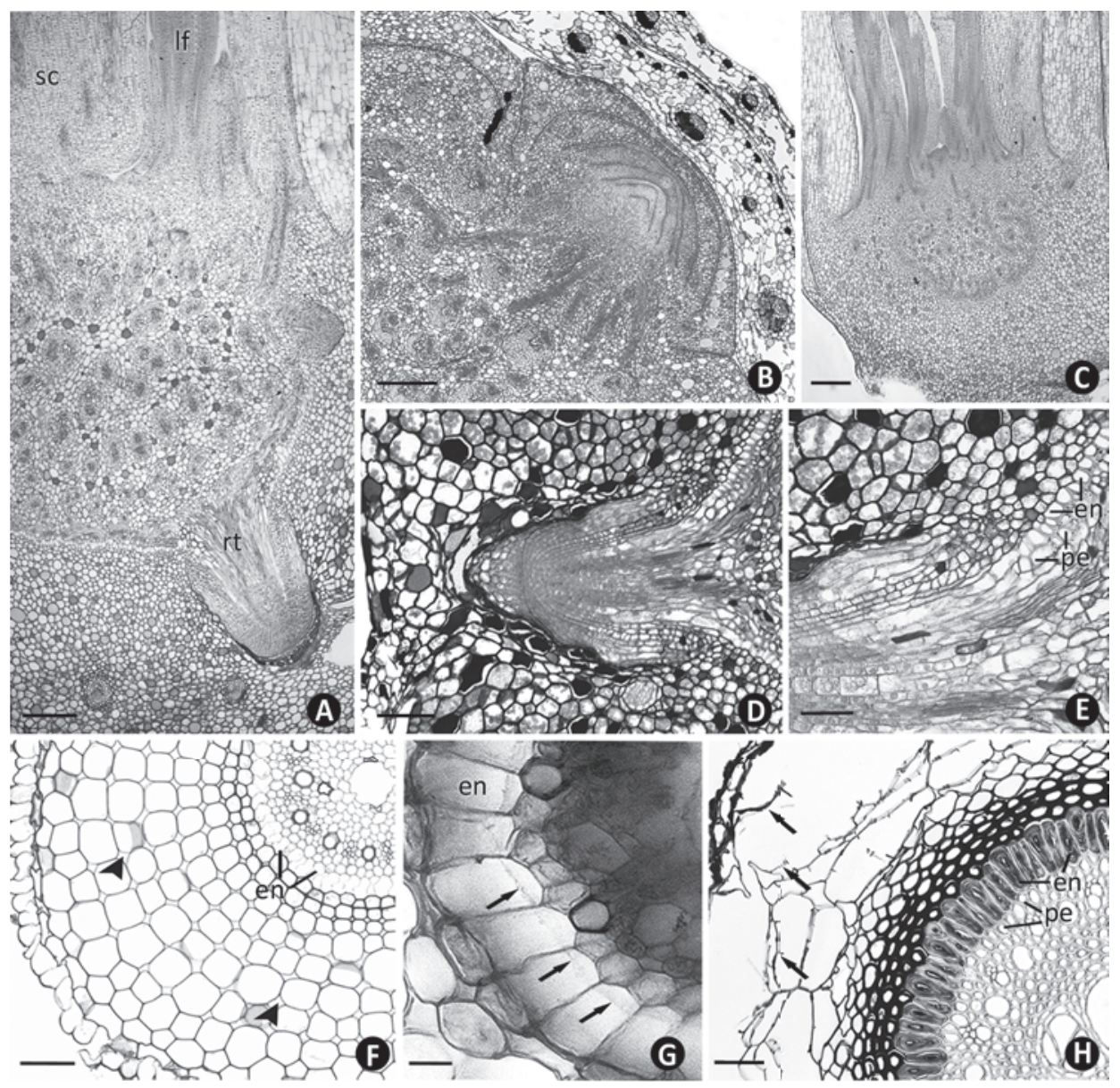

Fig. 2 - Anatomical aspects of transverse and longitudinal sections of rhizome and roots of Cyperaceae species: Cyperus laxus L. and Fimbristylis dichotoma Vahl. A. Fimbristylis dichotoma, longitudinal section of the mature rhizome showing root, leaf primordia and scape in protrusion; B. Cyperus laxus, transverse section of the mature rhizome; C-E. Fimbristylis dichotoma, mature rhizome; C. Longitudinal section showing leaf primordia; D. Transverse section showing roots protrusion; E. Detail of roots protrusion; F. Cyperus laxus, general view of the young root showing the separation of the cell walls (arrows); G-H. Fimbristylis dichotoma, roots; G. Detail of the root showing Casparian strips in the endodermal cells (arrows); H. General view of the mature root showing lyse of the cell walls (arrows) and endodermis and pericycle with thick-walled cells. en $=$ endodermis; lf = leaf; pe = pericycle; $\mathrm{rt}=$ root; $\mathrm{sc}=$ scape. $\operatorname{Bars}=200 \mu \mathrm{m}(\mathbf{A}, \mathbf{B}) ; 100 \mu \mathrm{m}(\mathbf{C}, \mathbf{D})$; $50 \mu \mathrm{m}(\mathbf{E}, \mathbf{F}, \mathbf{H}) ; 20 \mu \mathrm{m}(\mathbf{G})$.

In the apical meristem region of the rhizome, leaves and scapes are formed (Fig. 2A-C). In this region, the continuity between the ground meristem and the procambial strands of the rhizome and the leaves and scapes is observed (Fig. 2A-C). In the young leaf of Cyperus laxus (non-Kranz), the mesophyll cells differentiate from the ground meristem, and the vascular bundles differentiate from 
the procambium (Fig. 3A-C). The mature leaf presents mesophyll cells that are distributed in a regular way (Fig. 3B-C), and the vascular bundles are collateral and surrounded by two sheaths (Fig. 3B-C). The outer bundle sheath (endodermis - en) originates from the innermost layer of the ground meristem and possesses thin-walled cells in the mature leaf (Fig. 3A-C). The inner bundle sheath (pericycle - pe) is derived from the outermost layer of the procambium and possesses thick-walled cells at maturity (Fig. 3A-C).

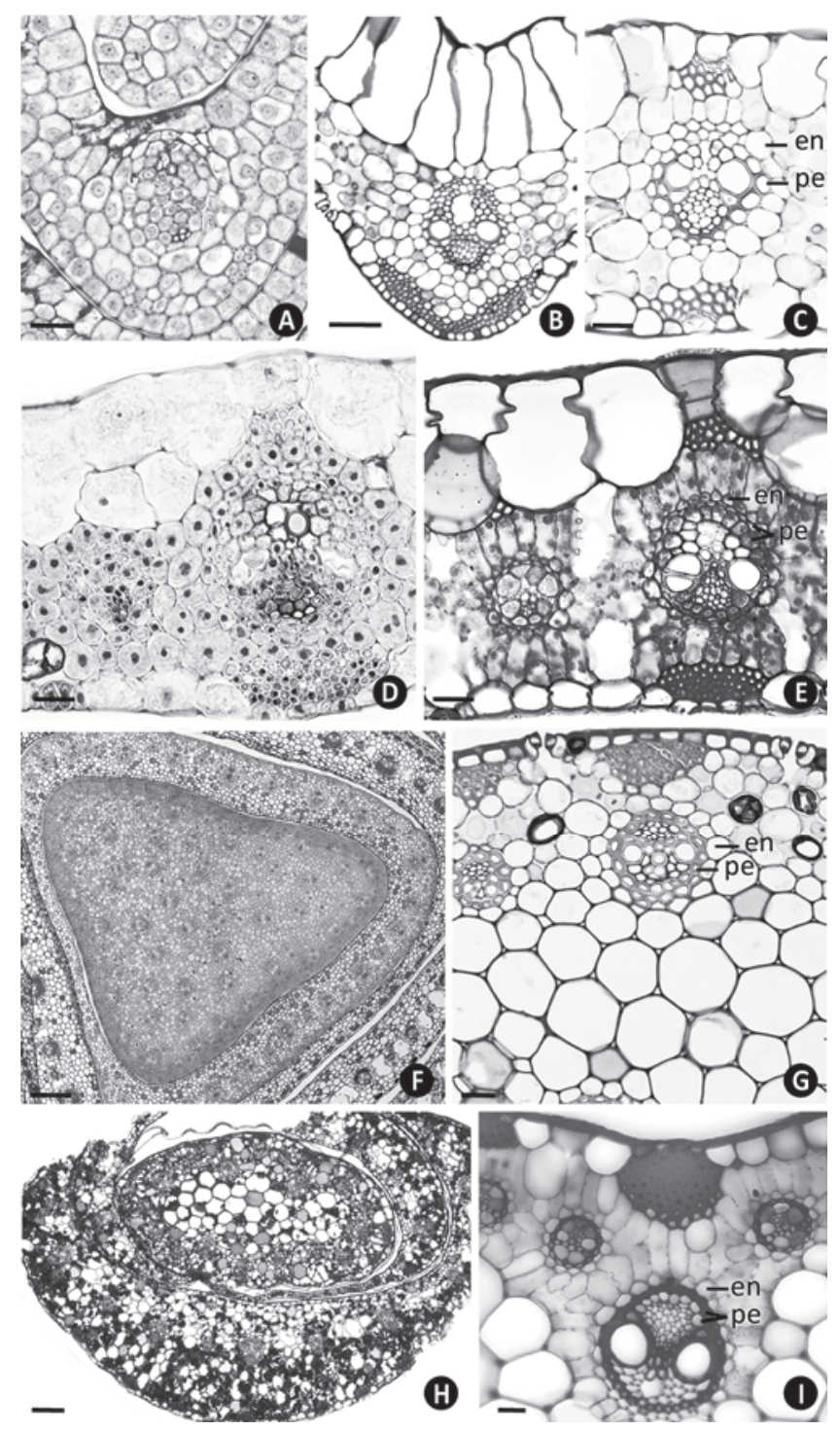

Fig. 3 - Anatomical aspects of transverse sections of leaves and scapes of Cyperaceae species: Cyperus laxus L. and Fimbristylis dichotoma Vahl. A-C. Cyperus laxus. A. Detail of the young leaf in the midrib region; B-C. Detail of the mature leaf; B. Midrib; C. Mesophyll; D-E. Fimbristylis dichotoma; D. Young leaf; E. Mature leaf; F-G. Cyperus laxus; F. General view of the young scape; G. Detail of the mature scape; H-I. Fimbristylis dichotoma; H. General view of the young scape; I. Detail of the mature scape. en $=$ endodermis; pe $=$ pericycle. Bars: $100 \mu \mathrm{m}(\mathrm{F}) ; 50 \mu \mathrm{m}(\mathbf{A}$, $\mathbf{B}, \mathbf{C}, \mathbf{H}) ; 20 \mu \mathrm{m}(\mathbf{D}, \mathbf{E}, \mathbf{G}, \mathbf{I})$. 
Fimbristylis dichotoma has Kranz anatomy of the fimbristyloid subtype, with vascular bundles that are surrounded by three sheaths. In the young leaf, the mesophyll precursor cells divide successively and after elongating their walls, the cells distribute radially around the vascular bundles (Fig. 3D-E). The outer bundle sheath (endodermis - en) originates from the innermost layer of the ground meristem and presents thin-walled cells at maturity (Fig. 3D-E). The middle sheath contains thick-walled cells, and thin-walled cells with chloroplasts constitute the inner sheath; both of these cell types are derived from the procambium and constitute the pericycle (pe) (Fig. 3D, E).

In the rhizome, the apical meristem also forms the scapes. In Cyperus laxus, the scape is triangular (Fig. 3F) with mesophyll cells that are distributed in a regular way on the periphery of the organ (Fig. $3 \mathrm{G})$. The vascular bundles distribute randomly in the medullar parenchyma and are surrounded by two sheaths; the outer sheath is the endodermis (en) and the inner sheath is the pericycle (pe) (Fig. 3F-G). In Fimbristylis dichotoma, the scape is elliptical and possesses vascular bundles that distribute cylindrically around the organ periphery (Fig. 3H). The vascular bundles are surrounded by the mesophyll cells that are distributed radially and three sheaths; the outer sheath constitutes the endodermis (en), and the middle and inner sheaths constitute the pericycle (pe) (Fig. 3I).

\section{DISCUSSION}

Cyperus laxus (non-Kranz) and (Kranz) have similarities in their first stages of development and in the anatomical structures of their roots and rhizomes. These species differ only in the anatomical structures of their leaves and scapes, and these differences reflect the photosynthetic types $\mathrm{C}_{3}$ and $\mathrm{C}_{4}$, respectively, which form structure non-Kranz and Kranz.

As it was observed for the germination of the two species studied, the emergence of the coleoptiles before the primary root is common in other Cyperaceae species (Goetghebeur 1998, Tillich 2007). In the two species from this study, the adventitious roots originated from the pericycle in the rhizome, an occurrence that has been described to other Cyperaceae species (Leite et al. 2009, Lima and Menezes 2009) and monocotyledons (Menezes et al. 2005, Cattai and Menezes 2010). The study of the presence of the pericycle in other organs, not including the root, has often been neglected (Menezes et al. 2005). However, it has been reported that in the root, the pericycle forms lateral roots (Dubrovsky et al. 2011), and in the stem, the adventitious roots originate from the pericycle (Menezes et al. 2005, Sorin et al. 2005).

In addition to forming adventitious roots, the pericycle in the rhizome of Cyperus laxus and Fimbristylis dichotoma, as in other monocotyledons, originates vascular plexus, promoting the vascular connection between the roots and rhizome (Simão and Scatena 2001, Alonso and Moraes-Dallaqua 2004, Menezes et al. 2005, Lima and Menezes 2009). For the species in this study, during the formation of adventitious roots, we observed that there was continuity between the root and rhizome of the vascular tissues and of the endodermis and pericycle. This formation has also been described in other Cyperaceae (Wills et al. 1980, Menezes et al. 2005) and monocotyledons, such as Agavaceae, Alismataceae, Commelinaceae, Eriocaulaceae, Heliconiaceae, Velloziaceae, Rapateceae and Zingiberaceae (Van Fleet 1942, Simão and Scatena 2001, Alonso and Moraes-Dallaqua 2004, Menezes et al. 2005, Cattai and Menezes 2010), reinforcing the presence of tissue continuity in vegetative organs.

In the adventitious roots of Cyperus laxus and Fimbristylis dichotoma, the cells of the inner cortex and part of the median cortex originate from the division of the precursor cells of the endodermis, which are termed endodermal initial cells by Menezes et al. (2005), and their derivatives. The meristematic role of the endodermis, which contributes to the formation 
of part of the root cortex, was demonstrated in other Cyperaceae and monocotyledons and was termed "proendodermis" by Van Fleet (1961) and "endodermis with meristematic activity" by Menezes et al. (2005). Therefore, the results presented here confirm the meristematic activity of the endodermis in cortex formation.

The successive divisions of the precursor cells of the endodermis and their derivatives promote the radial disposition of the cortical cells, as was observed in roots of the species in this study, in other monocotyledons (Williams 1947, Rodrigues and Estelita 2004, Menezes et al. 2005). This radial arrangement favors aerenchyma formation in roots (Seago et al. 2005), corroborating what has been described in the species studied here and in other Cyperaceae and monocotyledons (Rodrigues and Estelita 2004, Menezes et al. 2005, Seago et al. 2005, Leite et al. 2009).

The endodermal cells in the studied species present Casparian strips when meristematic activity ceased, and after the cell-walls became thickened, as was described in other species of monocotyledons (Menezes et al. 2005, Leite et al. 2009, Lima and Menezes 2009). Casparian strips in the endodermis cells of young rhizomes of Cyperus laxus and Fimbristylis dichotoma were also observed, as well as, in other Cyperaceae and monocotyledons (Eiten 1969, Bendixen 1973, Govindarajalu 1974, Wills et al. 1980, Rodrigues and Estelita 2002, Alonso and Moraes-Dallaqua 2004, Menezes et al. 2005, Lima and Menezes 2009). Some authors consider the occurrence of endodermis in rhizomes as the innermost layer of the cortex, even without finding the Casparian strips (Will et al. 1980, Simão and Scatena 2001, Menezes et al. 2005). However, others authors employ other terms for the endodermis that is present in stems, such as "endodermoid sheath" (Tomlinson 1969, Metcalfe 1971, Gifford and Bayer 1995) and "starch sheath" (Esau 1965).

In the leaves of the species that have been studied, the endodermis corresponds to the vascular bundle sheath that originates from the ground meristem, as is seen in other Cyperaceae (Martins and Scatena 2011) and families of monocotyledons, such as Velloziaceae (Menezes et al. 2005), Heliconiaceae (Simão and Scatena 2001), Cannaceae (Alonso and Moraes-Dallaqua 2004) and Bromeliaceae (Proença and Sajo 2008). In leaves, as well as in stems, the occurrence of endodermis is generally related to Casparian strips (Priestley and Radcliffe 1924, Dickison and Weitzman 1996, Lersten 1997), leading to the use of other terms, such as "parenchymatous sheath" or "endodermoid sheath", instead of endodermis (Esau 1965).

The pericycle, like the endodermis, is continuous in all vegetative organs that have a primary structure. The pericycle in the leaves of the species that have been studied here has a procambial origin, and this origin is located inner to the endodermis. There is a consensus that the pericycle is present in roots; however, there are a few reports that suggest it is also present in stems and leaves (Altamura et al. 1998, Menezes et al. 2005, Leite et al. 2009). However, in accordance with the results presented here and those of other authors (Van Fleet 1961, Menezes et al. 2005), the endodermis and the pericycle are continuous in the vegetative organs.

The occurrence of suberin in the cell walls of the leaf vascular bundle sheath (mestome) in several monocotyledons was linked to Casparian strips that were present in the endodermis cells of the roots and subterranean stem, and therefore, were treated as endodermis (Menezes et al. 2005), endodermoid sheath (Brown 1975) and sheath like endodermis (Vecchia et al. 1999). However, in Cyperaceae and Poaceae species, it was demonstrated that this bundle sheath called mestome (Dengler et al. 1985, Soros and Dengler 2001) or outer pericycle (Martins and Scatena 2011), originates from the procambium, so, it cannot be named endodermis because it originates from the ground meristem.

The leaves and scapes of the species in this study differ structurally because of the presence of 
Kranz anatomy in Fimbristylis dichotoma and the absence of this kind of anatomy in Cyperus laxus. In Cyperaceae, this difference is caused by the arrangement of mesophyll cells around the vascular bundles and by the occurrence of chloroplasts in the inner bundle sheath cells (Soros and Dengler 2001). In Fimbristylis dichotoma, as well as in other Cyperaceae, Kranz anatomy also occurs in the scape (Estelita-Teixeira and Handro 1987, Rodrigues and Estelita 2003), which imparts to the plant a greater photosynthetic efficiency.

\section{ACKNOWLEDGMENTS}

We thank the anonymous reviewers for their valuable comments and sugestions, the Fundação de Amparo à Pesquisa do Estado de São Paulo (FAPESP) for a PhD grant (2008/09380-2) to $\mathrm{S}$. Martins and 2011/18275-0 for financial support to V.L. Scatena, and the Conselho Nacional de Desenvolvimento Científico e Tecnológico (CNPq) for financial support (301692/2010-6) and (471837/2011-3) to V. L. Scatena.

\section{RESUMO}

As espécies de Cyperaceae estão presentes em diferentes ecossistemas e constituem o extrato herbáceo. Das aproximadamente 5,500 espécies da família, um terço possui anatomia Kranz, representando uma importante característica da taxonomia e filogenia do grupo. Em Cyperus laxus L. (não Kranz) e Fimbristylis dichotoma Vahl (Kranz), o desenvolvimento começa com a germinação que é marcada pela emergência do coleóptilo, seguido da raiz primária, que é efềmera. $\mathrm{O}$ rizoma se origina do mesocótilo e promove a conexão vascular entre raízes, folhas e escapos. A continuidade dos tecidos é evidenciada pela presença de endoderme e periciclo em todos os órgãos vegetativos. Folhas e escapos diferem entre as duas espécies estudadas no arranjo das células do mesofilo, que é regular em Cyperus laxus (não Kranz) e dispostas radialmente em Fimbristylis dichotoma (Kranz). Também diferem no número de bainhas vasculares: duas em Cyperus laxus (não Kranz) e três em Fimbristylis dichotoma (Kranz). A bainha externa em ambas as espécies constitui a endoderme, e a bainha interna em Cyperus laxus e a mediana e a interna em Fimbristylis dichotoma constituem o periciclo.

Palavras-chave: periciclo, endoderme, estrias de Caspary, plântula.

\section{REFERENCES}

Alonso AA AND Moraes-Dallaqua MA. 2004. Morfoanatomia do sistema caulinar de Canna edulis KerrGawler (Cannaceae). Rev Bras Bot 29: 229-239.

Altamura MM, Zaghi D, SAlvi G, DE Lorenzo G AND BELLINCAMPI D. 1998. Oligogalacturonides stimulate pericycle cell wall thickening and cell divisions leading to stoma formation in tobacco leaf explants. Planta 204: 429-436.

Alves M, Araújo AC, Prata AP, VitTa FA, Hefler SM Trevisan R, Gil AB, Martins S And Thomas WW. 2009. Diversity of Cyperaceae in Brazil. Rodriguésia 60: 771-782.

BENDIXEN LE. 1973. Anatomy and sprouting of yellow nutsedge tubers. Weed Sci 21: 501-503.

BROWN WV. 1975. Variations in anatomy, associations, and origins of Kranz tissue. Am J Bot 62: 395-402.

BRUhL JJ AND WILSON KL. 2007. Towards a comprehensive survey of $\mathrm{C}_{3}$ and $\mathrm{C}_{4}$ photosynthetic pathway in Cyperaceae. In: COLUMBUS JT, FRIAR EA, HAMILTON CW, PORTER JM, PRINCE LM AND SIMPSON MG (Eds), Monocots: comparative biology and evolution, Claremont: Rancho Santa Ana Botanic Garden, p. 99-148.

BRYSON CT AND CARTER R. 2008. The significance of Cyperaceae as weeds. In: NACZI RF AND FORD BA (Eds), Sedges, uses, diversity, and systematic of the Cyperaceae, Missouri: Monogr Syst Bot Mo Bot Gard 108, p. 15-101.

Cattai M And Menezes NL. 2010. Primary and secondary thickening in the stem of Cordyline fruticosa (Agavaceae). An Acad Bras Cienc 82: 653-662.

Dengler NG, Dengler RE AND Hattersley PW. 1985. Differing ontogenetic origins of PCR ("Kranz") sheaths in leaf blades of $\mathrm{C}_{4}$ grasses (Poaceae). Am J Bot 72: 284-302.

Dickison WG AND WEITZMAN AL. 1996. Comparative anatomy of the young stem, node, and leaf of the Bonnetiaceae, including observations on a foliar endodermis. Am J Bot 83: 405-418.

DUBROVSKY JG, NAPSUCIALY-MENDIVIL S, DUCLERCQ J, CHENG Y, SHISHKPVA S, IVANCHENKo MG, FrimL J, MuRPHY AS AND BENKOVÁ E. 2011. Auxin minimum defines a developmental window for lateral root initiation. New Phytol 191: 970-983.

EITEN LT. 1969. The vegetative anatomy of Eleocharis interstincta (Vahl) Roem. and Schult. Arqs Bot Est S Paulo 4: 187-228.

ESAU K. 1965. Plant anatomy, New York: J Wiley \& Sons. 
ESTELITA-TEIXEIRA ME AND HANDRO W. 1987. Kranz pattern in leaf, scape and bract of Cyperus and Fimbristylis species. Rev Bras Bot 10: 105-111.

FEDER N AND O'BRIEN TP. 1968. Plant microtechnique: some principles and new methods. Am J Bot 55: 123-142.

GIFFORD EM AND BAYER DE. 1995. Developmental anatomy of Cyperus esculentus (yellow nutsedge). I J Plant Sci 156: 622-629.

Goetghebeur P. 1998. Cyperaceae. In: KUBITZKI K, HUBER H, RUDALL PJ, STEVENS PS AND STÜTZEL $\mathrm{T}$ (Eds), The families and genera of vascular plants, Berlin: Springer-Verlag, p. 141-190.

Govaerts R, Simpson DA, Goetghebeur P, WiLson KL, EGOROVA T AND BRUHL J. 2007. World checklist of Cyperaceae, Kew: The Board of Trustees of the Royal Botanical Garden.

Govindarajalu E. 1974. The systematic anatomy of south Indian Cyperaceae: Cyperus L. subgen. Juncellus, Cyperus subgen. Mariscus and Lipocarpha R. Br. Bot J Linn Soc 68: 235-266.

HEFLER SM AND LONGHI-WAGNER HM. 2010. A contribuição da anatomia foliar para taxonomia das espécies de Cyperus L. subg. Cyperus (Cyperaceae) ocorrentes no sul do Brasil. Acta Bot Bras 24: 708-717.

JOHANSEN D. 1940. Plant microtechnique, New York: McGraw-Hill Book Co. Inc.

LEITE KRB, FRANÇA F AND SCATENA VL. 2009. Anatomia de espécies anfíbias de Cyperaceae de lagoas do semi-árido, BA, Brasil. Acta Bot Bras 23: 786-796.

LERSTEN NR. 1997. Occurrence of endodermis with a Casparian strip in stem and leaf. Bot Rev 63: 265-272.

LIMA VFGAP AND MENEZES NL. 2009. Morpho-anatomical analysis of the rhizome in species of Scleria Berg. (Cyperaceae) from Serra do Cipó (MG). Braz Arch Biol Technol 52: 1473-1483.

MARTINS S AND SCATENA VL. 2011. Bundle sheath ontogeny in Kranz and non-Kranz species of Cyperaceae (Poales). Aust J Bot 59: 554-562.

Menezes NL, Silva DC, Arruda RCO, Melo-de-Pinna GF, Cardoso VA, CAstro NM, Scatena VL AND SCREMIN-DiAS E. 2005. Meristematic activity of the endodermis and the pericycle in the primary thickening in monocotyledons. Considerations on the "PTM". An Acad Bras Cienc 77: 259-274.

MetCALFE CR. 1971. Anatomy of the monocotyledons: Cyperaceae, Oxford: Clarendon Press.

NACZI RFC. 2009. Insight on using morphologic data for phylogenetic analysis in sedges (Cyperaceae). Bot Rev 75: 67-95.

Priestley JH AND RAdCliffe FM. 1924. A study of the endodermis in the Filinineae. New Phytol 23: 161-193. Proença SL and Sajo MG. 2008. Rhizome and root anatomy of 14 species of Bromeliaceae. Rodriguésia 59: 113-128.
Rodrigues AC AND Estelita MEM. 2002. Primary and secondary development of Cyperus giganteus Vahl rhizome (Cyperaceae). Rev Bras Bot 25: 251-258.

Rodrigues AC AND ESTELITA MEM. 2003. Origin and structure of the Kranz tissue in bracts of Cyperus giganteus Vahl (Cyperaceae). Rev Bras Bot 26: 445-452.

RODRIGUES AC AND ESTELITA MEM. 2004. Anatomia da raiz de Cyperus giganteus Vahl (Cyperaceae) em desenvolvimento. Rev Bras Bot 27: 629-638.

ROESER KR. 1972. Die nadel der schwarzkiefer - massenprodikt und kunstwerk der nautr. Mikrokosmos 61: 33-36.

SAGE RF. 2004. The evolution of C4 photosynthesis. New Phytol 161: 341-370.

Seago Jl, Marsh LC, SteVens KJ, Soukup A, Votrubová O AND ENSTONE DE. 2005. A re-examination of the root cortex in wetland flowering plants with respect to aerenchyma. Ann Bot 96: 565-579.

SIMÃo DG AND SCATENA VL. 2001. Morphology and anatomy in Heliconia angusta Vell. and H. velloziana L. Emygd. (Zingiberales: Heliconiaceae) from the Atlantic forest of southeastern Brazil. Rev Bras Bot 24: 415-424.

SORIN C ET AL. 2005. Auxin and light control of adventitious rooting in Arabibdopsis require ARGONAUTE1. Plant Cell 17: 1343-1359.

SOROS CL AND DENGLER NG. 1996. Leaf morphogenesis and growth in Cyperus eragrostis (Cyperaceae). Can J Bot 74: $1753-1765$.

Soros CL AND Dengler NG. 2001. Ontogenetic derivation and cell differentiation in photosynthetic tissues of $\mathrm{C}_{3}$ and $\mathrm{C}_{4}$ Cyperaceae. Am J Bot 88: 992-1005.

TILLICH HJ. 2007. Seedling diversity and the homologies of seedling organs in the order Poales (Monocotyledons). Ann Bot 100: 1-17.

TOMLINSON PB. 1969. Comelinales - Zingibelares. In: Metcalfe CR (Ed), Anatomy of the monocotyledons. Vol. 3, London: Oxford University Press, p. 193-294.

VAN FLEET DS. 1942. The development and distribution of the endodermis and an associated oxidase system in Monocotyledonous plants. Am J Bot 29: 1-15.

VAN FLEET DS. 1961. Histochemistry and function of the endodermis. Bot Rev 27: 165-220.

Vecchia FD, CUCCATO F, LA Rocca N, LARChER W AND RASCIO N. 1999. Endodermis-like sheaths in the submerged freshwater macrophyte Ranunculus trichophyllus Chaix. Ann Bot 83: 93-97.

WILLIAMS BC. 1947. The structure of the meristematic root tip and origin of the primary tissues in the roots of vascular plants. Am J Bot 34: 455-462.

WILLS GD AND BRISCOE GA. 1970. Anatomy of purple nutsedge. Weed Sci 18: 631-635.

Wills GD, HoAGLAND RE AND PAUL RN. 1980. Anatomy of yellow nutsedge (Cyperus esculentus). Weed Sci 28: 432-437. 